Historic, archived document

Do not assume content reflects current scientific knowledge, policies, or practices. 
435

United States

Department of Agriculture

Forest

Service

North Central

Forest Experiment

Station

Resource

Bulletin NC-63

uiss

\section{A Net Volume Equation for Indiana}

W. Brad Smith and Carol A. Weist
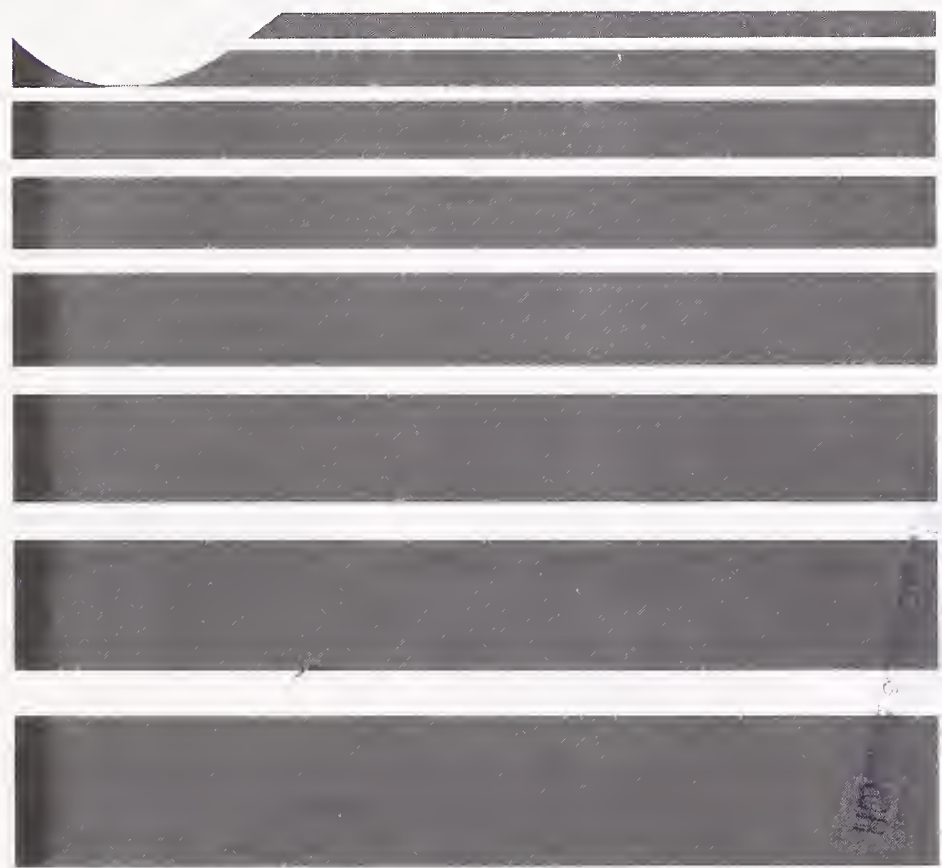

SEP $\quad 61983$
P. O. BOX 1950

SUMMERVILLE, SC 29484

WESTVACO RD., 1.26 \& U.S. 17 A

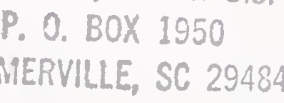


North Central Forest Experiment Station Forest Service-U.S. Department of Agriculture 1992 Folwell Avenue

St. Paul, Minnesota 55108

Manuscript approved for publication September 29, 1982 1982 


\title{
A NET VOLUME EQUATION FOR INDIANA
}

\author{
W. Brad Smith, Mensurationist, \\ and Carol A. Weist, Computer Programmer
}

Recent development of computerized forest growth models has increased the need for accurate tree volume equations. The Stand and Tree Evaluation and Modeling System (STEMS) ${ }^{1}$, recently calibrated for the Central States, is a computerized distance independent tree growth model. The volume equation and coefficients presented in this report will form the basis of tree volume estimates for STEMS in the eastern Central States. The equation and coefficients will also be used to estimate tree volumes in the next Indiana forest inventory to be conducted by North Central Forest Experiment Station. The equation is suitable for use on digital computers by foresters, land managers, researchers, and others in need of net volume-per-tree estimates for large forest areas. Both board foot and cubic foot volume can be estimated for most tree classes and species.

\section{HOW THE EQUATION AND COEFFICIENTS WERE DEVELOPED}

Based on Gevorkiantz and Olsen's (1955) composite volume tables for the Lake States, we used equations developed by Robert N. Stone (Appendix) to estimate the cubic foot and board foot volume in each tree. Stone's equations compute gross volume in a tree from three measurements-diameter breast height (d.b.h.), merchantable height, and top diameter outside bark (t.d.o.b.). This estimated volume was then corrected for differences in bark thickness between species and a field estimate of cull volume was subtracted to arrive at net volume.

The equation form selected for the volume regressions was a modified Weibull. It has been demonstrated that Weibull-type functions offer the wide range of flexibility necessary to accommodate a diverse set of biologically sound curve forms (Yang et al. 1978). The following equation form was selected

${ }^{1}$ For more information on STEMS, see: Belcher, $D$. L.; Holdaway M. R.; Brand G. J. A Description of STEMS: The stand and tree evaluation and modeling system. Gen. Tech. Rep. NC-79. St. Paul, MN: U.S. Department of Agriculture, Forest Service, North Central Forest Experiment Station; (in prep.) for the Indiana regression:

$\mathrm{V}=\mathrm{A} \cdot \mathrm{SI}^{\mathrm{B}}\left[1-\mathrm{e}^{-\mathrm{C} \cdot \mathrm{DBH}^{\mathrm{D}}}\right]$

Where the dependent variable $\mathrm{V}$ is net volume of the tree, and the independent variables $\mathrm{SI}$ and $\mathrm{DBH}$ are tree site index and diameter at breast height, respectively. The value of $e$ is the constant base of natural logarithm (2.71828). A, B, C, and D are the equation coefficients. The upper asympote, $\mathrm{A} \cdot \mathrm{SI}^{\mathrm{B}}$, is a function of site index. The $C$ and $D$ parameters are the basis of Weibull curve flexibility and are determinants of scale and shape, respectively. An example of this function can be seen graphically in fig. 1 .

The equation coefficients were developed using field data collected on 12,162 trees in Indiana during the 1967 inventory. Data included d.b.h., merchantable height, t.d.o.b., site index, and tree class. For sawtimber-size trees, measurements were taken at both the sawtimber and poletimber limits of merchantability. ${ }^{2}$ Field crews also estimated the volume of board foot and cubic foot cull in each tree (USDA Forest Service 1964).

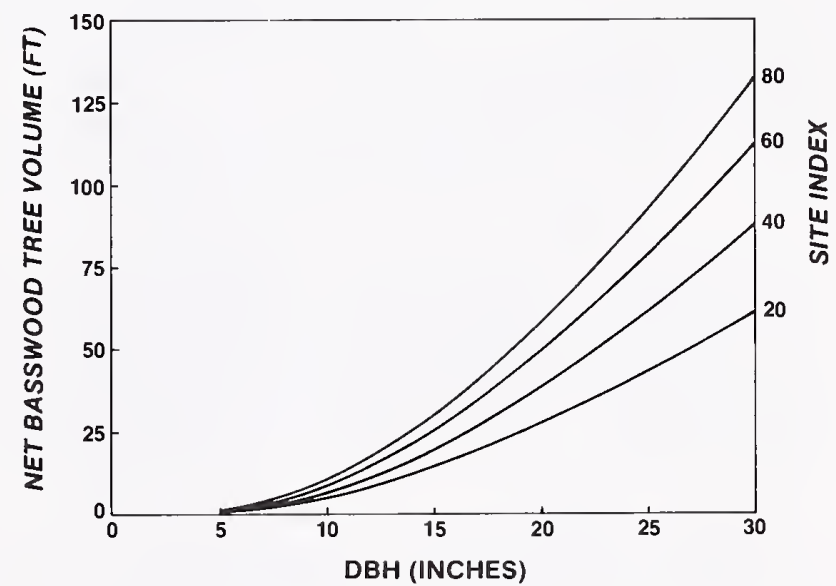

Figure 1.-Net cubic foot volume of desirable and acceptable basswood trees by $\mathrm{DBH}$ and selected site index levels.

${ }^{2}$ The poletimber merchantability limits include trees 5.0 inches d.b.h. and over, from a 1-foot stump to a minimum of 4.0-inch t.d.o.b., or to the point where the central stem breaks into limbs. Dimensions for sawtimber are 9.0-inch d.b.h. to a minimum 7-inch t.d.o.b. for softwoods and 11.0-inch d.b.h. to a minimum 9.0-inch t.d.o.b. for hardwoods. 
Cubic foot and board foot equation coefficients were developed for each of three tree class categories: "desirable and acceptable", "rough and short-log", and "rotten" (See Appendix). The groupings of species for the equations were primarily determined by the number of observations and the similarity of bole form among species. Species for which no observations were available were assigned equations on the basis of bole form. (See Appendix for species and species groups).

A computerized nonlinear regression program (Marquardt method) was used to fit the above equation to the tree data. The resulting coefficients and statistics for each regression are given in tables 1-3 (Appendix).

Because the average site index may be used when site index is unknown, the only other data needed to determine tree volumes using this model are species, d.b.h., and tree class. The average site index for Indiana species based on USDA Forest Service inventory data is found in tables 1-3 (Appendix). Note that net volume per tree varies greatly, therefore, these equations should be applied to an adequate sample over a large forest area.

\section{HOW TO USE THE EQUATION}

1. Select the appropriate species group and coefficients from tables 1-3.

2. Substitute these coefficients in the above equation.

3. Solve the equation to obtain net volume.

For example, to compute the cubic foot volume of a 15-inch acceptable basswood tree with a site index of 60 we would first obtain the coefficients for basswood from table 1 . Substituting into the general net volume equation:

$\mathrm{V}=\mathrm{A} \cdot \mathrm{SI}^{\mathrm{B}}\left[1.0-\mathrm{e}^{-\mathrm{C} \cdot \mathrm{DBH}^{\mathrm{D}}}\right]$

$\mathrm{V}=16.882(60.0)^{.572}\left[1.0-\mathrm{e}^{-.0001(15.0)^{2.707}}\right]$

$\mathrm{V}=(16.882) \cdot(10.402) \cdot(1.0-.859)$

$\mathrm{V}=24.85$ cubic feet

This volume may be verified graphically in figure 1 .
LITERATURE CITED

Gevorkiantz, S. R.; Olsen. L. R. Composite volume tables for timber and their application in the Lake States. Lake States Tech. Bull. 1104. St. Paul, MN: U.S. Department of Agriculture, Forest Service, Lake States Forest Experiment Station; 1955. $51 \mathrm{p}$.

Hahn, Jerold T. Local net volume equations for Missouri. Gen. Tech. Rep. NC-15. St. Paul, MN: U.S. Department of Agriculture, Forest Service, North Central Forest Experiment Station; 1975. 8 p.

Hahn, Jerold T. A local net volume equation for Iowa. Res. Note NC-199. St. Paul, MN: U.S. Department of Agriculture, Forest Service, North Central Forest Experiment Station; 1976. 4 p.

U.S. Department of Agriculture, Forest Service. Forest Service Handbook. Supplement FSH-4809.11Forest Survey Handbook; 1964.

Yang, R. C.; Kozek, A.; Smith, J. H. G. The potential of Weibull-type functions as flexible growth curves. Can. J. For. Res. 8: 424-431; 1978.

\section{APPENDIX}

\section{VOLUME EQUATIONS}

Stone uses the following dependent variables in his equation to estimate cubic foot volume (cv): diameter at breast height (D), merchantable height $(\mathrm{H})$, and diameter outside bark at merchantable height (T).

$$
\begin{aligned}
\mathrm{CV}= & \left(3.0086 \mathrm{X} 10^{-3}+\mathrm{S} 1+\mathrm{S} 2+\mathrm{S} 3+\mathrm{S} 4+\right. \\
& \mathrm{S} 5+\mathrm{S} 6+\mathrm{S} 7+\mathrm{S} 8) \cdot 79.0
\end{aligned}
$$

where

$$
\begin{aligned}
& \mathrm{S} 1=\left(2.0355 \times 10^{-3}\right) \mathrm{D}, \\
& \mathrm{S} 2=\left(-3.0018 \times 10^{-3}\right) \mathrm{T}, \\
& \mathrm{S} 3=\left(6.2381 \times 10^{-5}\right) \mathrm{D}^{2}, \\
& \mathrm{~S} 4=\left(2.5705 \times 10^{-5}\right) \mathrm{D}^{2} \cdot \mathrm{H}, \\
& \mathrm{S} 5=\left(-7.0090 \times 10^{-6}\right) \mathrm{H}^{2}, \\
& \mathrm{~S} 6=\left(3.6708 \times 10^{-5}\right) \mathrm{H} \cdot \mathrm{T}^{2}, \\
& \mathrm{~S} 7=\left(8.1400 \times 10^{-10}\right) \mathrm{D}^{2} \cdot \mathrm{H}^{3}, \text { and } \\
& \text { S8 }=\left(-1.90000 \times 10^{-9}\right) \mathrm{D}^{2} \cdot \mathrm{H}^{2} \cdot \mathrm{T} .
\end{aligned}
$$


Stone's board foot volume equation as modified by Hahn $(1975,1976)$ is as follows:

$$
\begin{aligned}
\mathrm{BV}= & 17.7488+7.3846 \cdot \mathrm{CV}-2.3523 \cdot \mathrm{D}-.89945 \cdot \mathrm{H} \\
& +2.0726 \cdot \mathrm{T}
\end{aligned}
$$

where

$$
\begin{aligned}
\mathrm{BV}= & \text { board foot volume (International } 1 / 4 \text {-inch } \\
& \text { rule). }
\end{aligned}
$$

\section{DEFINITION OF TERMS}

Desirable trees. - Live trees that have no serious defects limiting present or prospective use, have relatively high vigor, and have no visible signs of pathogens that may result in death or serious deterioration before rotation age. They would be favored by forest managers in silvicultural operations.

Acceptable trees. - Live trees that have no serious defects limit present or prospective use but that have pathogens or damage affecting quality.

Rough trees. - Live trees that do not contain at least one merchantable 12 -foot $\log$, now or prospectively, because of roughness, poor form, or noncommercial species.

Rotten trees.--"Rough" trees in which more than 50 percent of the cull volume is rotten.

Short-log trees. - Live sawtimber sized trees that contain at least one merchantable from 8- to 11foot saw $\log$ but not a 12 -foot saw $\log$, now or prospectively.

\section{PRINCIPAL TREE SPECIES OF INDIANA ${ }^{3}$}

\section{SOFTWOOD SPECIES}

Pines

Shortleaf pine ........... Pinus echinata

Virginia pine ........... Pinus virginiana

Red pine ............... Pinus resinosa

White pine ............... Pinus strobus

Scotch pine ............. Pinus sylvestris

Other softwoods

Eastern redcedar...... Juniperus virginiana Tamarack .............. . Larix laricina Baldcypress.......... Taxodium distichum

${ }^{3}$ The common and scientific names are based on: Little, Elbert L. Check list of native and naturalized trees of the United States. Agric. Handbk. 541. Washington, D.C.: U.S. Department of Agriculture, Forest Service; 1979. $375 p$.

\section{HARDWOOD SPECIES}

White oaks

White oak .............. Quercus alba

Swamp white oak ........ Quercus bicolor Bur oak ........... Quercus macrocarpa Swamp chestnut oak ....QQuercus michauxii Chinkapin oak ...... Quercus muehlenbergii Chestnut oak ............ Quercus pinus Post oak.............. Quercus stellata Red oaks

Northern red oak .......... Quercus rubra Cherrybark oak ..... Quercus falcata var. pagodaefolia Shumard oak ........ Quercus shumardii Black oak ............ Quercus velutina Scarlet oak ............ Quercus coccinea Southern red oak .........Quercus falcata Shingle oak........... Quercus imbricaria Pin oak ............Quercus palustris Hickories

Mockernut hickory ........ Carya tomentosa Shagbark hickory ............ Carya ovata Shellbark hickory ......... Carya laciniosa Pecan ................ Carya illinoensis Pignut hickory ............. Carya glabra

Bitternut hickory ....... Carya cordiformis Hard maple ............... Acer saccharum Soft maples

Red maple................ Acer rubrum

Silver maple ........... Acer saccharinum

Boxelder ................ Acer negundo Beech ................. Fagus grandifolia Sweetgum .......... Liquidambar styraciflua Blackgum ......... Nyssa sylvatica var. biflora Ashes

White ash .......... Fraxinus americana Black ash .............. Fraxinus nigra Green ash ......... Fraxinus pennsylvanica Blue ash ........ Fraxinus quadrangulata Cottonwood.............. Populus deltoides Aspens

Balsam poplar ........ Populus balsamifera Bigtooth aspen....... Populus grandidentata Quaking aspen......... Populus tremuloides Basswood.................. Tilia americana Yellow-poplar.......... Liriodendron tulipifera Walnuts

Black walnut ........... Juglans nigra

Butternut ............. Juglans cinerea

Black cherry............. Prunus serotina 


\section{Elms}

Winged elm Ulmus alata

American elm Ulmus americana

Siberian elm Ulmus pumila

Slippery elm .............. Ulmus rubra

Rock elm .............. Ulmus thomasii

Sycamore............. Platanus occidentalis

Other hardwoods

Yellow birch ......... Betula alleghaniensis

River birch ............... Betula nigra

Paper birch ........... Betula papyrifera

Ohio buckeye ............ Aesculus glabra

Hackberry ........... Celtis occidentalis

Northern catalpa.......... Catalpa speciosa

Flowering dogwood.......... Cornus florida

Common persimmon ... Diospyros virginiana

Honeylocust .......... Gleditsia triacanthos

Kentucky coffeetree ... Gymnocladus dioicus

Osage-orange .......... Maclura pomifera

Cucumbertree ........ Magnolia acuminata

Black locust ......... Robinia pseudoacacia

Black willow................ Salix nigra

Sassafras ............. Sassafras albidum

\section{METRIC EQUIVALENTS}

1,000 board feet (International 1/4-inch log rule) $=3.48$ cubic meters.

Breast Height $=1.37$ meters above the ground .1 cubic foot $=0.0283$ cubic meter.

1 foot $=30.48$ centimeters or 0.3048 meter

1 inch $=25.4$ millimeters or 2.54 centimeters or 0.0254 meter. 


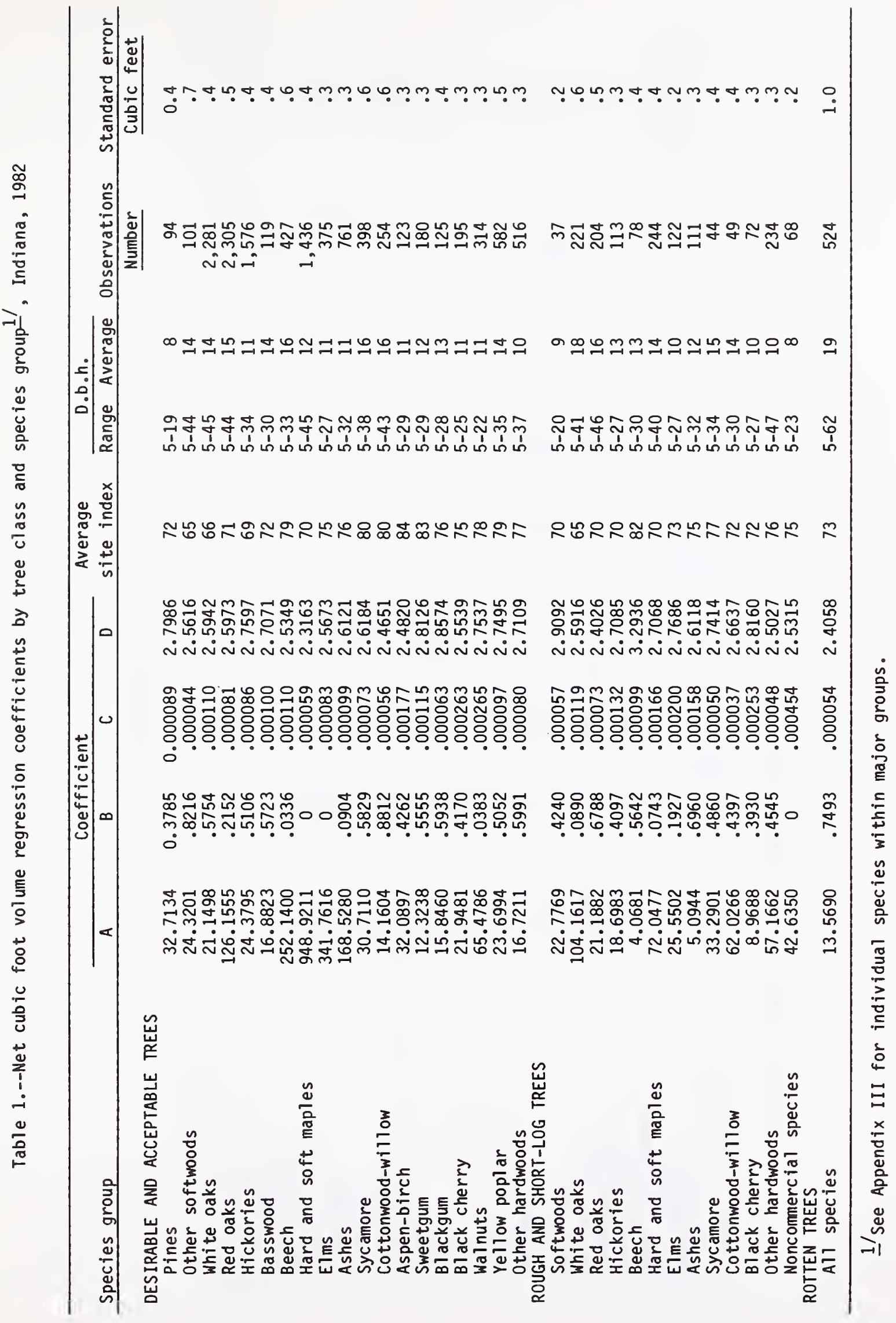




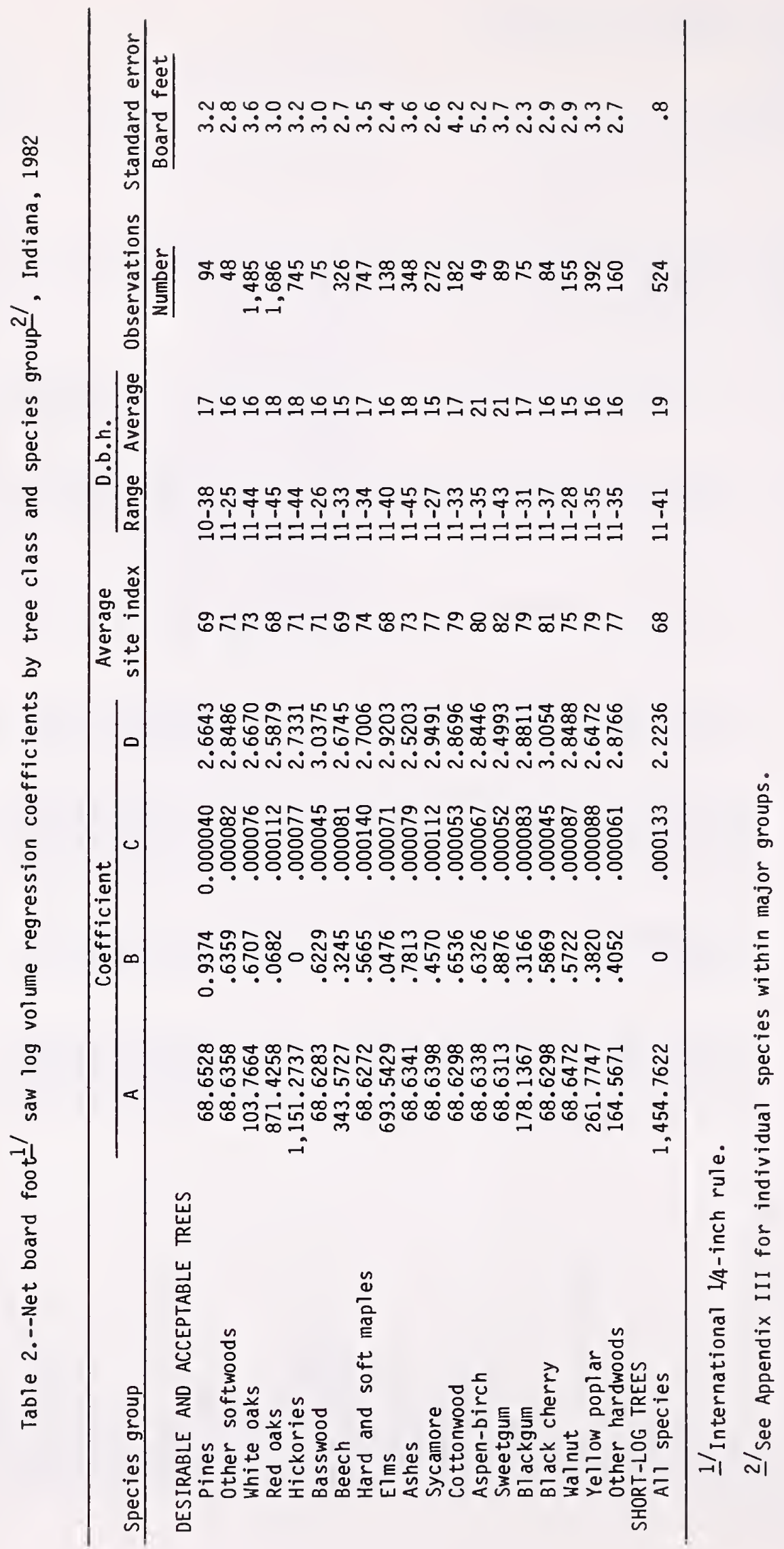




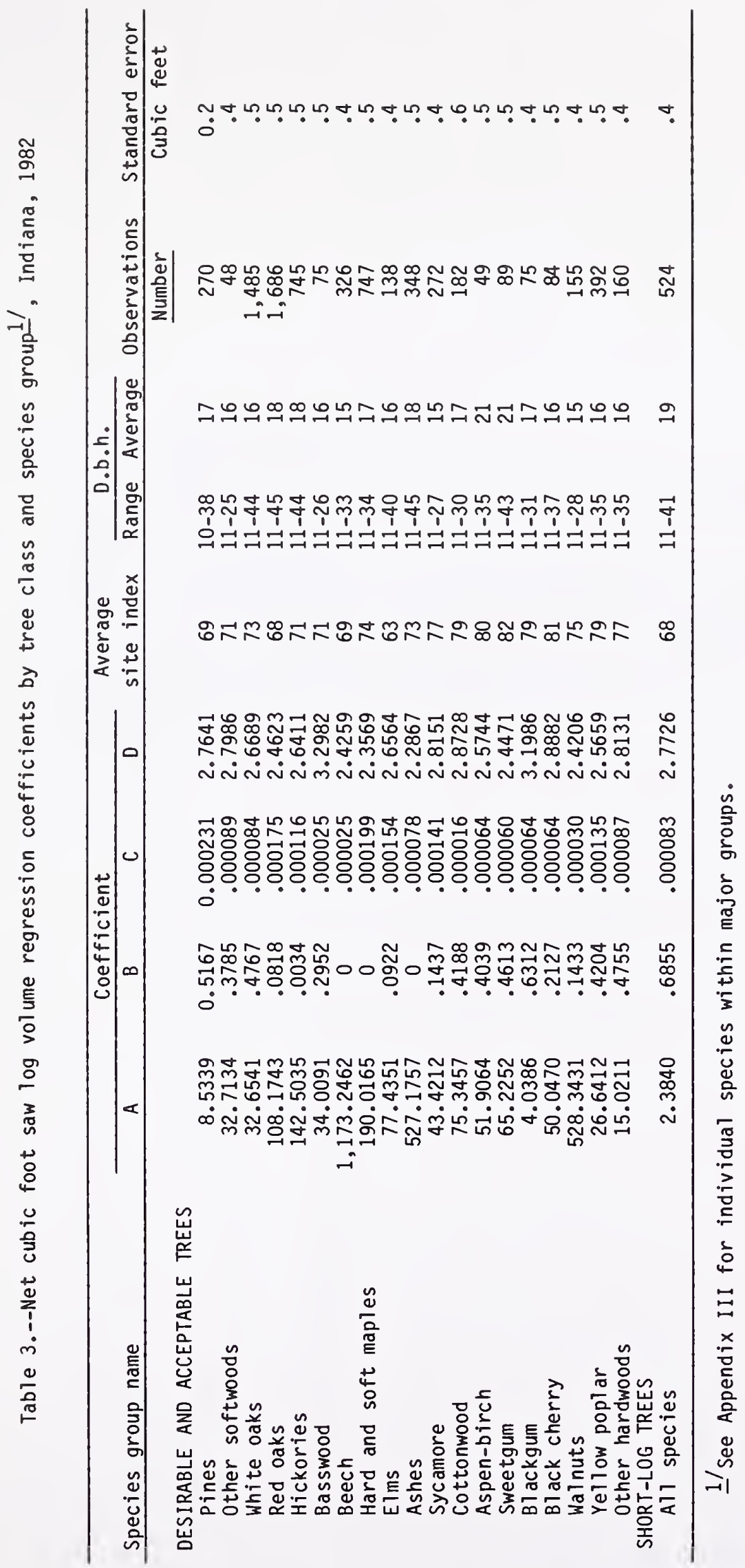



Smith, W. Brad; Weist, Carol A.

A net volume equation for Indiana. Res. Bull. NC-63. St. Paul, MN: U.S. Department Agriculture, Forest Service, North Central Forest Experiment Station; 1982.7 p.

Describes a Weibull-type volume equation for Indiana developed as part of the ongoing Resource Evaluation research in the Central States. Equation coefficients are presented by species groupings for both cubic foot and board foot volumes for three tree class categories.

KEY WORDS: Inventory, computer, growing-stock, cull, cubic foot, board foot, Weibull. 
